\title{
Concentration of furfuryl alcohol in fluid milk, dried dairy ingredients, and cultured dairy products
}

\author{
B. M. Wherry, Y. Jo, and M. A. Drake* \\ Department of Food, Bioprocessing, and Nutrition Science, Southeast Dairy Foods Research Center, North Carolina State University, \\ Raleigh 27695
}

\section{ABSTRACT}

Maillard reactions occur in dairy products during heat treatment. Furfuryl alcohol (FA) may be found in dairy products as a result of Maillard reactions. The recent posting in California Proposition 65 indicates that FA may be carcinogenic, and for this reason it is crucial to accurately measure FA concentrations in dairy products. The objective of this study was to identify an extraction and quantitation method for FA from dairy products and to determine FA concentrations in milk, dairy powders, and cultured dairy products. Solvent-assisted flavor extraction, solid-phase microextraction, stir bar sorptive extraction with gas chromatography-mass spectrometry and triple quadrupole mass spectrometry were compared for recovery of FA. Internal standards for the quantitation of FA (2-methyl-3-heptanone, furfuryl- $\mathrm{d}_{5}$ alcohol, 2,5-dimethylphenol, 5-methyl-2-furfuryl alcohol, and 5-methyl furfural) were also compared. Subsequently, fluid milk [high temperature, short time (HTST) and ultrapasteurized], whey protein isolates ( 3 mo-4 yr), whey protein concentrates $(3 \mathrm{mo}-4 \mathrm{yr})$, whole milk powders (1 yr), high and low heat skim milk powders (SMP; 0-8 yr), milk protein isolates ( $3 \mathrm{mo}-3 \mathrm{yr})$, milk protein concentrates ( 3 mo-3 yr), Cheddar cheese (mild, medium, sharp, and extra sharp), mozzarella cheese (whole and part skim), cottage cheese (nonfat, low fat, and full fat), sour cream (nonfat, low fat, and full fat), traditional yogurt (nonfat, low fat, and full fat), and Greek-style yogurt (nonfat; $\mathrm{n}=139$ products total) were evaluated. Furfuryl alcohol was extracted from products by headspace solid-phase microextraction followed by gas chromatography-triple quadrupole mass spectrometry using a ZB-5ms column $(30 \mathrm{~m} \times 0.25 \mathrm{~mm}$ $\times 0.25 \mu \mathrm{m}$; Phenomenex Inc., Torrance, CA). Furfuryl$\mathrm{d}_{5}$ alcohol was used as an internal standard. Each food was extracted in triplicate. Ultrapasteurized milks had

Received September 18, 2018.

Accepted December 20, 2018

*Corresponding author: maryanne_drake@ncsu.edu higher levels of FA than HTST milks (122.3 vs. 7.350 $\mu \mathrm{g} / \mathrm{kg}$ ). Furfuryl alcohol concentrations ranged from 0.634 to $26.55 \mu \mathrm{g} / \mathrm{kg}$ in whey protein isolates, 2.251 to $56.19 \mu \mathrm{g} / \mathrm{kg}$ in whey protein concentrates, 11.99 to $121.9 \mu \mathrm{g} / \mathrm{kg}$ in milk protein isolates, and 8.312 to 49.71 $\mu \mathrm{g} / \mathrm{kg}$ in milk protein concentrates, and concentrations increased with powder storage. High heat SMP had higher concentrations of FA than low heat SMP (11.8 vs. $1.36 \mu \mathrm{g} / \mathrm{kg}$ ) and concentrations increased with storage time. Concentrations of FA in Cheddar and mozzarella cheese ranged from 2.361 to $110.5 \mu \mathrm{g} / \mathrm{kg}$ and were higher than FA concentrations in cottage cheese or sour cream $(0.049-1.017 \mu \mathrm{g} / \mathrm{kg})$. These results suggest that FA is present at higher levels in dairy products that have been subjected to higher temperatures or have been stored longer. Sour cream and cottage cheese had lower levels of FA. Compared with other studies on food products with reported levels of FA, such as coffee (200-400 $\mu \mathrm{g} / \mathrm{g})$, dairy products have very low levels of FA.

Key words: furfuryl alcohol, dairy product, concentration

\section{INTRODUCTION}

Proposition 65 was enacted in 1986 to help consumers in California make informed decisions about protecting themselves from chemicals known to cause cancer, birth defects, or other reproductive harm (American Cancer Society, 2015). More than 800 chemicals are that on the Proposition 65 list are known to the state of California to cause cancer or birth defects. These chemicals may be naturally occurring or synthetic. They can be additives or ingredients in pesticides, household products, food, drugs, dyes, or solvents (California Environmental Protection Agency, 2018a). If any food, drug, or household product has the potential to contain one of the listed chemicals, then the product must be labeled appropriately. Several compounds in foods are on the Proposition 65 list including acrylamide, which is increased in certain plant-based foods during the cooking process at high temperatures; methyl mercury, which 
is bioaccumulated in seafood over time and is often found in canned tuna; and lead, which can be found in chocolate because of natural uptake by the cocoa plant (California Environmental Protection Agency, 2018b).

Furfuryl alcohol (FA) was recently added to the list of chemicals in Proposition 65 as a carcinogen (California Environmental Protection Agency, 2018c). Furfuryl alcohol has been the subject of safety research and studies have documented that FA can become a DNA-reactive intermediate that has a mutagenic effect (Glatt and Sommer, 2006). Monien et al. (2011) detected DNA adducts in Salmonella typhimurium that was exposed to FA, and Høie et al. (2015) reported enhanced adduct levels in colon and liver cells of mice that had been exposed to FA. The safety of FA poses an issue for the food industry because FA is formed during heat treatment of food products due to Maillard reactions or by sugar degradation due to high processing temperatures (Patton, 1950; Yaylayan and Keyhani, 2000; Swasti and Murkovic, 2012).

Furfuryl alcohol is responsible for burnt (Wang and Kays, 2000; Lee et al., 2006), cooked-sugar (Bonvehi, 2005), and rubber-like odors in foods (Karagül-Yüceer et al., 2002), and has been documented in many roasted and heated food sources and baby foods. Albouchi and Murkovic (2018) documented amounts of FA in soybeans $(25-100 \mu \mathrm{g} / \mathrm{g})$, coffee $(200-400 \mu \mathrm{g} / \mathrm{g})$, beans $(10-120 \mu \mathrm{g} / \mathrm{g})$, rice $(5-20 \mu \mathrm{g} / \mathrm{g})$, wheat $(25-90 \mu \mathrm{g} / \mathrm{g})$, corn $(10-20 \mu \mathrm{g} / \mathrm{g})$, chickpeas $(20-130 \mu \mathrm{g} / \mathrm{g})$, and sesame seeds $(10-20 \mu \mathrm{g} / \mathrm{g})$. Furfuryl alcohol levels in baby foods ranged from 1.25 to $21.14 \mu \mathrm{g} / \mathrm{g}$ (Condurso et al., 2018). In general, FA formation can be affected by food composition, $\mathrm{pH}$, heating time and temperature, and storage time (Condurso et al., 2018), and FA concentrations increased in foods that received higher heat treatments during roasting (Albouchi and Murkovic, 2018).

Although there is increasing attention to FA levels in foods, only a few methods have been applied for FA determination in foods: liquid chromatography (LC)-MS (Swasti and Murkovic, 2012), GC-MS (Pérez-Prieto et al., 2003; Vázquez et al., 2007; Condurso et al., 2018), and nuclear magnetic resonance spectroscopy (Monakhova et al., 2015; Okaru and Lachenmeier, 2017). Among these methods, GC-MS coupled with headspace solid-phase microextraction (HS-SPME) has primarily been applied to measure furan derivatives, including FA, due to its advantages of being fast, simple, and having solvent-free preparation along with its ability to extract highly volatile furan derivatives (Condurso et al., 2018). However, to our knowledge, no previous studies have compared different extraction techniques and described a validated and quantitative method to determine FA in foods.
Dairy foods have desirable flavors that are formed by microorganisms, enzymes, thermal treatments, storage conditions, and chemical reactions. Safety concerns surrounding FA pose an issue to the dairy industry because the compound has been detected in dairy products. Previous studies have noted the presence of FA in milk powders (Karagül-Yüceer et al., 2002), Cheddar cheese and parmesan cheese (Qian and Reineccius, 2002; Carunchia Whetstine et al., 2005), and sweet whey powder (Mahajan et al., 2004). However, FA amounts in a representative array of dairy products have not been documented. This paper had 2 objectives. The first was to find the most accurate and reliable technique for FA extraction and detection in dairy products. The second objective was to report concentrations of FA in fluid milk, Cheddar cheese, mozzarella cheese, cottage cheese, sour cream, yogurt, milk and whey protein powders, and skim milk powders (SMP).

\section{MATERIALS AND METHODS}

\section{Experimental Overview}

Two experiments were conducted as part of this study. Experiment 1 included the selection of an appropriate extraction procedure and an appropriate internal standard for the quantitation of FA in dairy products. Four methods were tested for the extraction and detection of FA: headspace-solid phase microextraction-gas chromatography-triple quadrupole mass spectrometry (HS-SPME-GC-MS/MS), headspace-solid-phase microextraction-gas chromatography-mass spectrometry (HS-SPME-GC-MS), stir-bar sorptive extraction-gas chromatography-mass spectrometry (SBSE-GC-MS), and direct solvent extraction-solvent-assisted flavor evaporation (DSE-SAFE). Skim milk was used as the test medium (HTST pasteurized, purchased locally), and 2-methyl-3-heptanone (Sigma Aldrich, St. Louis, MO) was used as the internal standard. Subsequently, 5 internal standards were evaluated with the selected extraction method. Once an extraction method was optimized, FA concentrations were documented in 139 dairy products (experiment 2).

\section{Experiment 1: Comparison of Extraction and Detection Methods for FA}

Sample Preparation. For HS-SPME-GC-MS and HS-SPME-GC-MS/MS, $5 \mathrm{~mL}$ of milk were placed in a 20-mL amber SPME vial with steel screw tops containing silicone septa faced in Teflon (Microliter Analytical, Suwanee, GA). Twenty microliters of internal standard (2-methyl-3-heptanone, $81 \mu \mathrm{g} / \mathrm{kg}$ in methanol) was added to each sample for quantitation. For SBSE- 
GC-MS, magnetic stir bars coated with polydimethylsiloxane $($ PDMS; $10 \times 0.5 \mathrm{~mm}$, Gerstel, Linthicum, MD) were added to $10 \mathrm{~mL}$ of milk along with $20 \mu \mathrm{L}$ of internal standard in a $10-\mathrm{mL}$ amber SPME vial (Microliter Analytical) and rotated on a magnetic stir plate at $900 \mathrm{rpm}$ for $60 \mathrm{~min}$ at $25^{\circ} \mathrm{C}$. After sample extraction, stir bars were rinsed with HPLC grade water (Fisher Scientific, Hampton, NH) and dried briefly. For DSESAFE, milks were extracted by ether extraction and distilled by SAFE glassware (Evans et al., 2009). The SAFE extracts were separated into acidic and neutral/ basic fractions (described in DSE-SAFE analysis) and injected separately onto GC-MS.

HS-SPME-GC-MS/MS Analysis. The GC-MS/ MS was performed using an Agilent 7890B GC applied to Agilent 7000C triple quadrupole MS (Agilent Technologies Inc., Santa Clara, CA). The sample preparation and SPME-GC-MS/MS method were modified from the method used by Jo et al. (2018). Separations were performed on a ZB-5ms column (30 m length $\times$ $0.25 \mathrm{~mm}$ i.d. $\times 0.25 \mu \mathrm{m}$ film thickness; Phenomenex Inc., Torrance, CA). Helium was used as a carrier gas at constant flow of $1 \mathrm{~mL} / \mathrm{min}$. Vials were equilibrated for $25 \mathrm{~min}$ at $35^{\circ} \mathrm{C}$ with $4 \mathrm{~s}$ pulsed $250 \mathrm{rpm}$ agitation. A 3 phase 50/30 $\mu \mathrm{m}$ DVB/CAR/PDMS (Supelco, Bellefonte, PA) 1-cm fiber was used for analysis. The SPME fiber was exposed to the samples for $40 \mathrm{~min}$ at a depth of $31 \mathrm{~mm}$. The fiber was retracted and injected at $50 \mathrm{~mm}$ in the GC inlet for $5 \mathrm{~min}$. The GC oven was initially held at $35^{\circ} \mathrm{C}$ for 3 min with gradual increases of $10^{\circ} \mathrm{C} / \mathrm{min}$ to $150^{\circ} \mathrm{C}$, held for $1 \mathrm{~min}$, then raised at a rate of $20^{\circ} \mathrm{C} / \min$ to $250^{\circ} \mathrm{C}$, and maintained for $5 \mathrm{~min}$. The MS transfer line was maintained at $250^{\circ} \mathrm{C}$ with the quadrupole at $150^{\circ} \mathrm{C}$ and source at $250^{\circ} \mathrm{C}$. The flow rate of helium quench gas and nitrogen collision gas was 1.0 and $2.5 \mathrm{~mL} / \mathrm{min}$, respectively. The MS/MS was operated by previously optimized multiple reaction monitoring (Table 1) for FA. Triplicate analyses were performed on each sample. On the basis of MS results, relative abundance was calculated using 2-methyl3-heptanone as the internal standard.
HS-SPME-GC-MS Analysis. Volatile compounds were extracted using SPME followed by Agilent 7820 GC with 5975 MSD (Agilent Technologies Inc.) equipped with ZB- $5 \mathrm{~ms}$ column $(30 \mathrm{~m}$ length $\times 0.25 \mathrm{~mm}$ i.d. $\times 0.25 \mu \mathrm{m}$ film thickness; Phenomenex Inc.). The sample preparation and SPME-GC-MS method were modified from the method used by White et al. (2013). Sample introduction was accomplished using a CTC Analytics CombiPal Autosampler (Zwingen, Switzerland). Vials were equilibrated for 25 min at $35^{\circ} \mathrm{C}$ with 4 s pulsed $250 \mathrm{rpm}$ agitation. A 3 phase $50 / 30 \mu \mathrm{m}$ DVB/ CAR/PDMS (Supelco) fiber was used for all analysis. The SPME fiber was exposed to the samples for $40 \mathrm{~min}$ at depth $3.1 \mathrm{~cm}$. The fiber was retracted and injected at $5.0 \mathrm{~cm}$ in the GC inlet for $5 \mathrm{~min}$. Samples were held at $5^{\circ} \mathrm{C}$ before fiber exposure. The $\mathrm{GC}$ oven temperature was $40^{\circ} \mathrm{C}$ for 3 min with gradual increases of $10^{\circ} \mathrm{C} /$ min to $90^{\circ} \mathrm{C}, 5^{\circ} \mathrm{C} / \mathrm{min}$ to $200^{\circ} \mathrm{C}$ held for $10 \mathrm{~min}$, and $20^{\circ} \mathrm{C} / \mathrm{min}$ to $250^{\circ} \mathrm{C}$ held for $5 \mathrm{~min}$. Inlet temperature was $250^{\circ} \mathrm{C}$ and set to splitless mode. A constant flow rate of $1 \mathrm{~mL} / \mathrm{min}$ (helium) was maintained throughout. The MS transfer line was maintained at $250^{\circ} \mathrm{C}$ with the quad at $150^{\circ} \mathrm{C}$ and source at $250^{\circ} \mathrm{C}$. Selective ion mode for ions 98 (FA) and 128 (2-methyl-3-heptanone) was performed to identify compounds of interest. Furfuryl alcohol was quantified by relative abundance using 2-methyl-3-heptanone as an internal standard.

$S B S E-G C$-MS Analysis. The SBSE-GC-MS analyses were performed using an Agilent 7890B series GC and Agilent inert 5977A MSD (Agilent Technologies Inc.) equipped with a ZB-5ms column (30 m length $\times$ $0.25 \mathrm{~mm}$ i.d. $\times 0.25 \mu \mathrm{m}$ film thickness; Phenomenex Inc.). The analysis parameters were modified from the method used by Park and Drake (2016). Polydimethylsiloxane stir bars $(10 \times 0.5 \mathrm{~mm}$, Gerstel $)$ and thermal desorption unit tubes (Gerstel) were conditioned before analysis for $1 \mathrm{~h}$ at $300^{\circ} \mathrm{C}$. Stir bars were injected using an autosampler (MPS Autosampler, Gerstel) and desorbed on a thermal desorption unit in combination with a CIS-4 PTV injector (Gerstel). Volatile compounds from the stir bars were thermally desorbed at $280^{\circ} \mathrm{C}$ assisted

Table 1. Multiple reaction monitoring transition of furfuryl alcohol (FA) and internal standards for GC-MS/MS ${ }^{1}$

\begin{tabular}{|c|c|c|c|c|c|c|c|c|c|}
\hline Compound & $\begin{array}{l}\mathrm{RT} \\
(\mathrm{min})\end{array}$ & $\begin{array}{l}\text { Precursor } \\
\text { ion }(m / z)\end{array}$ & \multicolumn{6}{|c|}{ Product ion } & $\begin{array}{l}\mathrm{S} / \mathrm{N} \\
\text { ratio }\end{array}$ \\
\hline 2-Methyl-3-heptanone & 10.9 & 128 & 85 & 3 & 86 & 3 & 71 & 10 & 33.97 \\
\hline 5-Methyl furfuryl alcohol & 11.5 & 112 & 96 & 5 & 69 & 15 & - & - & 249.1 \\
\hline 5-Methyl furfural & 11.3 & 110 & 54 & 15 & 80 & 5 & - & - & 2,001 \\
\hline
\end{tabular}

${ }^{1}$ Properties of FA and internal standards evaluated for use in quantifying $\mathrm{FA} . \mathrm{RT}=$ retention time; $\mathrm{CE}=$ collision energy; $\mathrm{S} / \mathrm{N}=$ signal to noise. 
by cryofocusing at $-100^{\circ} \mathrm{C}$ for $5 \mathrm{~min}$. Initial $\mathrm{GC}$ oven conditions were $40^{\circ} \mathrm{C}$ for $3 \mathrm{~min}$ with gradual increases of $10^{\circ} \mathrm{C} / \mathrm{min}$ to $90^{\circ} \mathrm{C}$, and $5^{\circ} \mathrm{C} / \mathrm{min}$ to $200^{\circ} \mathrm{C}$ held for 10 min, then $20^{\circ} \mathrm{C} / \mathrm{min}$ to $250^{\circ} \mathrm{C}$ held for $10 \mathrm{~min}$. Purge time was set to $1.2 \mathrm{~min}$ using helium as the carrier gas at a constant flow rate of $1 \mathrm{~mL} / \mathrm{min}$. A 3 -min solvent delay was included in the MS acquisition parameters. The MS transfer line was maintained at $280^{\circ} \mathrm{C}$ with the quad at $150^{\circ} \mathrm{C}$ and source at $230^{\circ} \mathrm{C}$. A combination of scanning from 40 to $200 \mathrm{~m} / z$ and selective ion mode for ions 98 (FA) and 128 (2-methyl-3-heptanone) was performed to identify compounds of interest. On the basis of MS results, relative abundance was calculated using 2-methyl-3-heptanone as the internal standard.

DSE-SAFE Analysis. Milks were extracted according to the methods of Milo and Reineccius (1997), with some modifications. Two aliquots of $80 \mathrm{~mL}$ of milk were placed into 2 Teflon bottles (capacity of 250 $\mathrm{mL}$ ) with Tefzel closures (160 mL total for each milk; Nalgene, Rochester, NY). Ethyl ether $(50 \mathrm{~mL}$, Fisher Scientific) and $80 \mu \mathrm{L}$ of internal standard were added to each bottle. The mixture was shaken for $30 \mathrm{~min}$ on a Rotomix type 50800 (Thermolyne, Dubuque, IA) at high speed. The bottles were then centrifuged at $735 \times$ $g$ for $10 \mathrm{~min}$ at $25^{\circ} \mathrm{C}$ to separate the solvent phase from the mixture, which was subsequently collected into a glass jar. The procedure was repeated twice with $50 \mathrm{~mL}$ of ethyl ether. The extract was concentrated to $120 \mathrm{~mL}$ under a constant stream of nitrogen gas.

Solvent extracts were distilled by SAFE (Ace Glassware, Vineland, NJ) with an assembly similar to those described by Evans et al. (2009). The glass SAFE head, with the 2-L round-bottom flask attached, was connected to 2 glass traps. The bases of the primary trap (for receiving the final distilled solvent extract) and the secondary trap (for waste) were both submerged in liquid nitrogen by suspension over nitrogen-filled insulated Nalgene buckets. The liquid nitrogen was replaced throughout the extraction so that the liquid nitrogen level remained constant. The temperature of the round bottom flask maintained at $40^{\circ} \mathrm{C}$ by submerging the base of the flask in a water bath. Vacuum was reached in the glassware using a rough pump/turbo pump combination. The solvent extract was introduced drop-wise into the vacuum system. Distillation was carried out for $45 \mathrm{~min}$ under vacuum $(13.33 \mathrm{mPa})$. After distillation, the distillate was collected in an amber glass jar, filtered through anhydrous sodium thiosulfate (VWR International, Radnor, PA) to remove residual water, and concentrated under a stream of nitrogen gas to 20 $\mathrm{mL}$. The concentrated distillate was transferred to a 50-mL screw-top glass tube for phase separation.

To separate the distillate into neutral/basic and acid fractions, the concentrated distillate was first washed twice with $3 \mathrm{~mL}$ of sodium bicarbonate $(0.5 \mathrm{M}$; Fisher Scientific) and mixed vigorously. After washing, the aqueous phase was placed into another glass tube. This washing and aqueous layer removal was repeated twice. The resulting ether layer, which will now be referred to as the neutral/basic fraction, was then filtered through anhydrous sodium sulfate (J. T. Baker, Phillipsburg, NJ) to remove any residual water and concentrated to $0.5 \mathrm{~mL}$ under a stream of nitrogen gas. The aqueous phase, which will now be referred to as the acidic fraction, was acidified through the addition hydrochloric acid (18\% wt/vol; Sigma Aldrich) until a $\mathrm{pH}$ of 2 to 2.5 was reached. Five milliliters of diethyl ether was added to the acidic fraction and mixed vigorously. The ether phase was removed and collected in a separate glass tube. This process was repeated twice. The acidic fraction was then filtered through anhydrous sodium thiosulfate to remove residual water and concentrated to $0.5 \mathrm{~mL}$ under a stream of nitrogen gas.

One microliter of each solvent extract fraction (neutral/basic and acidic) was injected in triplicate on an Agilent 7820 GC with 5975 MS (Agilent Technologies Inc.) with a ZB- $5 \mathrm{~ms}$ column $(30 \mathrm{~m}$ length $\times 0.25 \mathrm{~mm}$ i.d. $\times 0.25 \mu \mathrm{m}$ film thickness; Phenomenex Inc.). Injections were performed in the pulsed splitless mode. A 3.00-min solvent delay was included in the MS acquisition parameters. The GC oven was initially held at $40^{\circ} \mathrm{C}$ for $3 \mathrm{~min}$ with gradual increases of $10^{\circ} \mathrm{C} / \mathrm{min}$ to $90^{\circ} \mathrm{C}, 5^{\circ} \mathrm{C} / \mathrm{min}$ to $200^{\circ} \mathrm{C}$ held for $10 \mathrm{~min}$, and $20^{\circ} \mathrm{C} / \mathrm{min}$ to $250^{\circ} \mathrm{C}$ held for $5 \mathrm{~min}$. Selective ion mode for ions 98 (FA) and 128 (2-methyl-3-heptanone) was performed to identify compounds of interest. The FA was quantified by relative abundance using 2-methyl-3-heptanone as an internal standard. No quantifiable amount of FA was present in the basic fraction, so only the acid fraction was considered in calculations.

Method Selection. The optimal method was chosen by precision. Precision was determined by relative standard deviation percentage (RSD \%), and sensitivity, limit of detection [LOD; signal-to-noise $(\mathbf{S} / \mathbf{N})$ ratio of $3: 1$, and quantitation (LOQ; S/N of 10:1), as well as economic and temporal limitations. The LOD and LOQ determinations for each extraction method were generated from FA standards spiked with raw skim milk to account for background interference to be calculated into these limits.

Internal Standard Identification. Once the preferred method of extraction was selected, different internal standards were evaluated to determine the best internal standard for quantifying FA. Five different compounds were selected for testing: 2-methyl3-heptanone (Sigma Aldrich), 5-methyl furfuryl alcohol (BOC Sciences, Shirley, NY), 5-methyl furfural (Sigma Aldrich), 2,5-dimethylphenol (Sigma Aldrich), and 
furfuryl- $\mathrm{d}_{5}$ alcohol (CDN Isotopes, Quebec, Canada). Each standard $(20 \mu \mathrm{L}$ of $1 \mu \mathrm{L} / \mathrm{L}$ in methanol vol/vol) was spiked into skim milk and evaluated by HS-SPMEGC-MS/MS and injected with the conditions described previously for this extraction method. Internal standard peaks were analyzed using Agilent MassHunter quantitative and qualitative software (Agilent Technologies Inc.). The base peak (the most intensive/unique ion peak) was selected as precursor ions for each compound on the basis of the full-scan single MS (MS 1 Scan mode) of authentic standards. Following the selection of these precursor ions for compounds of interest, their product ions were optimized using different collision energies of $3,5,10,15,20,25$, or $30 \mathrm{~V}$ with nitrogen gas (product ion scan mode). Multiple reaction monitoring transition was developed with chosen collision energies that gave the most intense/unique product ion to each compound. The most intense product ion was chosen for the quantifier ion, and the second or third most intense product ions were selected for qualitative ions (Table 1). Dwell times were set to ensure 3 to 3.1 cycles over a peak. The $\mathrm{S} / \mathrm{N}$ ratio was determined from measuring the height of the peak of interest divided by the height of the noise in the chromatogram. The internal standard for FA quantitation was selected based on $\mathrm{S} / \mathrm{N}$ ratio and molecular similarity to $\mathrm{FA}$.

\section{Experiment 2: FA Concentrations in Dairy Foods}

After determining the best method of extraction and internal standard for quantitation (HS-SPME with GC-MS/MS with furfuryl- $\mathrm{d}_{5}$ alcohol), concentrations of FA in fluid milk, dried dairy ingredients, and cultured dairy products were determined.

Food Samples. Fluid skim milks ( $\mathrm{n}=12 ; 3$ different lots, processed in the North Carolina State University Dairy pilot plant, both HTST and direct steam injection (DSI)-ultrapasteurized (UP); 3 locally purchased HTST; 3 locally purchased UP); commercial dried dairy ingredients: whey protein isolate (WPI; 3 mo-4 yr), whey protein concentrate (WPC; 3 mo-4 yr), whole milk powder (WMP; 1 yr), and SMP (0-8 yr), milk protein isolate (MPI; 3 mo-3 yr), and milk protein concentrate (MPC; 3 mo-3 yr; $\mathrm{n}=59$ ); and commercial cultured dairy products: Cheddar cheese (mild, medium, sharp, and extra sharp), mozzarella cheese (whole and part skim), cottage cheese (nonfat, low fat, and full fat), sour cream (nonfat, low fat, and full fat), yogurt (nonfat, low fat, and full fat), and Greek-style yogurt (nonfat; $\mathrm{n}=68$ ), were evaluated.

The 3 lots of raw fluid skim milk $(0.1 \%$ fat, $3.3 \%$ protein) were obtained from North Carolina State University Dairy Enterprise System (Raleigh, NC), processed in the North Carolina State University Dairy pilot plant, and stored at $4^{\circ} \mathrm{C}$ until analysis within 24 $\mathrm{h}$ of processing. Skim milks were processed on a Microthermics EHVH pasteurization unit (Microthermics, Raleigh, NC) with a 2-stage homogenizer (GEA Niro Soavi, Parma, Italy) as described by Lee et al. (2017). For HTST treatment, raw skim milks were preheated to $60^{\circ} \mathrm{C}$, homogenized and pasteurized at $75^{\circ} \mathrm{C}$ for 15 $\mathrm{s}$, and cooled to $4^{\circ} \mathrm{C}$. For the DSI-UP milk, raw milks were also preheated to $90^{\circ} \mathrm{C}$, heated to $140^{\circ} \mathrm{C}$ for 2.3 $\mathrm{s}$ by DSI, then cooled to $85^{\circ} \mathrm{C}$ by vacuum cooling to remove both heat and added water. The DSI-UP milk was then homogenized and cooled to $4^{\circ} \mathrm{C}$. All milks were homogenized at $20.7 \mathrm{MPa}$ of total pressure with $3.4 \mathrm{MPa}$ on the second stage. Dried dairy ingredients were sourced from commercial facilities. Cultured dairy products were purchased locally (Raleigh, NC). A minimum of 2 lots from each product was evaluated. A total of 139 dairy products were evaluated.

$H S-S P M E-G C$ - $M S / M S$. Milk (5 mL) was dispensed into $20-\mathrm{mL}$ amber vials. Cheddar cheese and mozzarella cheese were prepared by first grating the sample and then placing $2.0 \mathrm{~g}$ into a $20-\mathrm{mL}$ amber vial. Sour cream and yogurt were first stirred and then 2.0 $\mathrm{g}$ of each was placed into a $20-\mathrm{mL}$ amber vial. Cottage cheese was first pureed to create a homogeneous sample and then $2.0 \mathrm{~g}$ was placed into a $20-\mathrm{mL}$ amber vial. For dried dairy ingredients, a $10 \%$ solution (wt/ vol) was made using MS grade deionized water (Fisher Chemical), and $5 \mathrm{~mL}$ of solution was placed in a 20$\mathrm{mL}$ amber vial. All samples had $20 \mu \mathrm{L}$ of furfuryl- $\mathrm{d}_{5}$ alcohol $(10 \mu \mathrm{L} / \mathrm{L}$ in methanol; vol/vol $)$ as an internal standard added. All samples were prepared in triplicate and analyzed using the method identified for extraction and quantitation. The GC-MS/MS analysis condition was identical as described above.

\section{Data Analysis}

All data were analyzed using XLSTAT software (version 2018.1, Addinsoft, New York, NY). Differences among sample means were determined by ANOVA followed by Tukey's honestly significant difference posthoc test at $95 \%$ confidence.

\section{RESULTS}

\section{Analysis Method Selection}

Furfuryl alcohol was detected by SPME-GC-MS/MS, SBSE-GC-MS, and SAFE-GC-MS, but was not detected at all by SPME-GC-MS in HTST skim milk (Table 2). Furfuryl alcohol was detected by SBSE-GC-MS, but the concentration was below the LOD as peaks were less than a 3:1 ratio to noise. Method selection between 
Table 2. Concentrations of furfuryl alcohol detected in commercial HTST skim milk using each method specified

\begin{tabular}{lcccc}
\hline Analysis method $^{1}$ & $\begin{array}{c}\text { HTST skim } \\
\text { milk }^{2}(\mu \mathrm{g} / \mathrm{kg})\end{array}$ & $\begin{array}{c}\text { Repeatability } \\
(\text { relative SD } \%)\end{array}$ & $\begin{array}{c}\mathrm{LOD}^{3} \\
(\mu \mathrm{g} / \mathrm{kg})\end{array}$ & $\begin{array}{c}\mathrm{LOQ}^{3} \\
(\mu \mathrm{g} / \mathrm{kg})\end{array}$ \\
\hline SPME-GC-MS/MS & $11.26^{\mathrm{a}}$ & $0.338^{\mathrm{c}}$ & $0.001^{\mathrm{b}}$ & $0.005^{\mathrm{c}}$ \\
SPME-GC-MS & $\mathrm{ND}^{4}$ & $\mathrm{NA}^{4}$ & $\mathrm{NA}$ & $\mathrm{NA}^{\mathrm{a}}$ \\
SBSE-GC-MS & $\mathrm{NQ}^{4}$ & $0.820^{\mathrm{b}}$ & $0.980^{\mathrm{a}}$ & $1.035^{\mathrm{b}}$ \\
SAFE-GC-MS & $9.671^{\mathrm{a}}$ & $12.021^{\mathrm{a}}$ & $0.894^{\mathrm{a}}$ & $5.271^{\mathrm{a}}$
\end{tabular}

${ }^{\mathrm{a}-\mathrm{c}}$ Means in a column not sharing the same letters are different $(P<0.05)$.

${ }^{1} \mathrm{SPME}=$ solid-phase microextraction; $\mathrm{SBSE}=$ stir bar sorptive extraction; SAFE $=$ solvent-assisted flavor extraction.

${ }^{2}$ Pasteurized skim milk as a test medium was purchased locally. Concentrations were calculated using 2-methyl3-heptanone as an internal standard.

${ }^{3} \mathrm{LOD}=$ limit of detection; $\mathrm{LOQ}=$ limit of quantification.

${ }^{4} \mathrm{NQ}=$ not quantifiable; $\mathrm{NA}=$ not applicable; $\mathrm{ND}=$ not detected.

SPME-GC-MS/MS and SAFE-GC-MS was determined based on precision (RSD \%), LOD, and LOQ. The SPME-GC-MS/MS had the lowest RSD (\%) compared with SBSE-GC-MS or SAFE-GC-MS, suggesting that results were more precise over a series of samples. The LOD and LOQ for SPME-GC-MS/MS were 0.001 and $0.005 \mu \mathrm{g} / \mathrm{kg}$, respectively. The SBSE-GC-MS and SAFE-GC-MS had higher LOD and LOQ values $(0.980$ and $1.035 \mu \mathrm{g} / \mathrm{kg}$ for SBSE, and 0.894 and $5.271 \mu \mathrm{g} / \mathrm{kg}$, respectively) than SPME-GC-MS/MS, which indicated that SPME-GC-MS/MS can be selected for analysis of FA in dairy products.

\section{Internal Standard Selection}

We selected internal standards with similar molecular structure and mass to FA. Internal standards were analyzed for retention time and $\mathrm{S} / \mathrm{N}$ ratio to determine the best compound for quantitation. Of the $5 \mathrm{com}-$ pounds tested, furfuryl- $\mathrm{d}_{5}$ alcohol had the highest $\mathrm{S} / \mathrm{N}$ ratio $(2,553$, Table 1$)$ compared with the other 4 compounds. 5-Methyl furfural had the second highest $\mathrm{S} / \mathrm{N}$ ratio $(2,001)$. Based on these results, SPME-GC-MS/ MS with furfuryl- $\mathrm{d}_{5}$ alcohol as the internal standard was selected for FA evaluation in dairy products.

\section{FA Concentration in Dairy Foods}

Fluid Milk. Furfuryl alcohol content in fluid milks ranged from 0.505 to $122.3 \mu \mathrm{g} / \mathrm{kg}$ (Table 3). Furfuryl alcohol content in commercial milks were similar in content to milks processed in the pilot plant after 1 wk of storage $(P>0.05)$. Milks processed in the pilot plant were tested over a 4 -wk shelf life to determine FA concentrations over time (Figure 1). Initially, UP milks had higher levels of FA than HTST pasteurized milks $(P<0.05)$ with a large decrease in FA content of UP milk in the first $7 \mathrm{~d}$. During the 4 wk shelf life period, FA content decreased in both HTST and UP milks $(P$ $<0.05)$.

Dried Dairy Ingredients. Skim milk powder is made by condensing skim milk through evaporation and then spray drying the condensed milk (solids content $\sim 50 \%$ ) into a powder (solids content $\sim 95 \%$ ). Higher heat SMP are defined by a higher heat treatment before the spray dryer than lower heat SMP. In SMP, FA was detected in the range of 0.771 to 80.58 $\mu \mathrm{g} / \mathrm{kg}$ (Table 3). High heat and low heat SMP were tested, and ranged from 0 to $8 \mathrm{yr}$ in age. For all ages tested, high heat SMP had higher levels of FA than low heat SMP $(P<0.05$; Figure 2$)$. Furfuryl alcohol content increased with longer storage times $(P<0.05)$.

Whey protein ingredients come from concentrated whey streams after cheese making. After whey is drained from cheese curd, it is pasteurized and concentrated through UF or microfiltration (or both) to a target protein content. The solution is then spray dried to a powder (solids content $\sim 95 \%$ ). Whey protein powders range in protein content from $34 \%$ to greater than $90 \%$ protein on a solids basis. In WPC ( $80 \%$ protein, wt/wt) and WPI (90\% protein, wt/wt), FA was detected in the range of 2.251 to $56.19 \mu \mathrm{g} / \mathrm{kg}$ and 0.634 to $26.55 \mu \mathrm{g} / \mathrm{kg}$, respectively (Table 3 ). The WPC and WPI powders tested ranged from 0 to $6 \mathrm{yr}$ of storage (Figure 3$)$. Whey protein powders showed no change in FA levels with storage time $(P>0.05)$.

Milk protein ingredients are any concentrated milk with protein content greater than $40 \%$ on a dry basis. Milk is concentrated by UF or microfiltration (or both) and then spray dried to a powder. In MPC and MPI, FA was detected in the range of 8.312 to $49.71 \mu \mathrm{g} / \mathrm{kg}$ and 11.99 to $121.9 \mu \mathrm{g} / \mathrm{kg}$, respectively (Table 3 ). The MPC powders were tested in a range of 0 to $6 \mathrm{yr}$ of storage (Figure 3 ) and MPI powders were tested in the 
range of 0 to $4 \mathrm{yr}$ of storage. Both MPC and MPI had increased levels of FA with longer storage times $(P<$ $0.05)$.

Cultured Dairy Products. Furfuryl alcohol content in Cheddar cheese ranged from 2.797 to $73.82 \mu \mathrm{g} / \mathrm{kg}$ (Table 3). Mild Cheddar cheese had the highest levels of FA $(P<0.05)$, and FA decreased with longer aging of cheese $(P<0.05)$. In cottage cheeses, FA ranged from 0.231 to $1.017 \mu \mathrm{g} / \mathrm{kg}$ (Table 3). Full-fat $(\mathrm{n}=5$ ), low-fat $(\mathrm{n}=4)$, and nonfat $(\mathrm{n}=2)$ cottage cheeses were tested. Fat content had no effect on FA $(P<0.05)$. Sour cream is, as the name suggests, a high-fat cultured dairy product. Full-fat sour cream must have a fat level of $18 \%$ (wt/wt) and low-fat sour cream must have a fat level of $9 \%(\mathrm{wt} / \mathrm{wt})$. In sour creams $(\mathrm{n}=11)$, FA concentrations ranged from 0.049 to $0.988 \mu \mathrm{g} / \mathrm{kg}$ (Table $3)$. Full-fat $(\mathrm{n}=7)$, low-fat $(\mathrm{n}=2)$, and nonfat $(\mathrm{n}=$ 2) sour cream samples were tested. Fat content had no effect on FA $(P<0.05)$. Yogurt is made by fermenting pasteurized milk to a $\mathrm{pH}$ of 4.6 or lower. Greek-style yogurt is further processed by straining the whey from the white mass after fermentation. Three Swiss-style yogurts (traditional type) and 6 Greek-style yogurts were tested for FA content. In Swiss-style yogurts, FA content ranged from 10.88 to $18.01 \mu \mathrm{g} / \mathrm{kg}$ and 4.963 to $144.6 \mu \mathrm{g} / \mathrm{kg}$ in Greek-style yogurts (Table 3).

\section{DISCUSSION}

Formation of FA in dairy products has been hypothesized and tested since the 1940s. Patton and Josephson (1949) isolated FA from heated skim milk by ether extraction. They theorized that FA was produced from the reduction of furfural by sulfhydryl groups in milk. Furfural is a Maillard reaction product from the reaction between lactose and lysine (Berg, 1993). Furfuryl alcohol was found in concentrated skim milk and weakly alkaline lactose solutions (Patton, 1950), suggesting that $\mathrm{pH}$ plays a role in FA formation. Hydroxymethylfurfural (HMF) was formed in lactose solutions with lower $\mathrm{pH}$ and FA was not detected. Furfuryl alcohol was formed in the same solutions at higher $\mathrm{pH}$, indicating a relationship between HMF and FA. However, HMF was not a precursor to FA because addition of HMF to skim milk before heating had no effect on the amount of FA (Patton, 1950). Patton (1950) predicted that FA was formed from lactose. Berg (1993) reported that FA was formed from degradation of lactulose, which is a product of lactose degradation and heat. Furfural and FA were also formed in stored casein (Ramshaw and Dunstone, 1969), likely a result of a Maillard reaction from lysine residues and lactose. Like Patton (1950) and Patton and Flipse (1957), Albouchi and Murkovic

Table 3. Ranges of furfuryl alcohol (FA) content in dairy products

\begin{tabular}{|c|c|c|}
\hline Category & Product $^{1}$ & $\begin{array}{c}\text { FA content }{ }^{2} \\
(\mu \mathrm{g} / \mathrm{kg})\end{array}$ \\
\hline \multirow[t]{2}{*}{ Fluid skim milk } & $\operatorname{HTST}(\mathrm{n}=6)$ & $0.505-7.350$ \\
\hline & DSI-UP $(\mathrm{n}=6)$ & $1.059-122.4$ \\
\hline \multirow[t]{16}{*}{ Cultured product } & Mild Cheddar (aged 3 mo; $\mathrm{n}=10$ ) & $9.688-73.82$ \\
\hline & Medium Cheddar (aged 3-6 mo; $\mathrm{n}=5$ ) & $2.361-67.51$ \\
\hline & Sharp Cheddar (aged 6 mo; $\mathrm{n}=9$ ) & $15.31-24.91$ \\
\hline & Extra sharp Cheddar (aged $12+$ mo; $\mathrm{n}=5$ ) & $2.797-16.17$ \\
\hline & Full fat sour cream $(\mathrm{n}=5)$ & $0.166-0.988$ \\
\hline & Low fat sour cream $(\mathrm{n}=2)$ & $0.261-0.306$ \\
\hline & Nonfat sour cream $(\mathrm{n}=2)$ & $0.564-0.812$ \\
\hline & Organic sour cream $(\mathrm{n}=2)$ & $0.049-0.226$ \\
\hline & $4 \%$ Cottage cheese $(n=5)$ & $0.284-0.716$ \\
\hline & Low fat cottage cheese $(n=4)$ & $0.405-1.017$ \\
\hline & Nonfat cottage cheese $(n=2)$ & $0.231-0.371$ \\
\hline & Mozzarella $(n=6)$ & $19.28-42.82$ \\
\hline & $2 \%$ Mozzarella $(\mathrm{n}=3)$ & $28.35-89.76$ \\
\hline & Organic mozzarella $(\mathrm{n}=2)$ & $59.93-110.5$ \\
\hline & Swiss-style yogurt $(\mathrm{n}=3)$ & $10.88-18.00$ \\
\hline & Greek-style yogurt $(\mathrm{n}=6)$ & $4.964-144.6$ \\
\hline \multirow[t]{7}{*}{ Dried product } & WPC $(3 \mathrm{mo}-4$ yr; $\mathrm{n}=13)$ & $2.251-56.19$ \\
\hline & WPI $(3$ mo- 4 yr; $\mathrm{n}=14)$ & $0.634-26.55$ \\
\hline & WMP $(1$ yr; $\mathrm{n}=3)$ & $49.14-112.6$ \\
\hline & High heat SMP $(0-8$ yr; $\mathrm{n}=7)$ & $11.81-80.58$ \\
\hline & Low heat SMP $(0-8 \mathrm{yr} ; \mathrm{n}=8)$ & $0.771-37.44$ \\
\hline & MPC $(3$ mo- -3 yr; $\mathrm{n}=8)$ & $8.312-49.71$ \\
\hline & MPI $(3 \mathrm{mo}-3$ yr; $\mathrm{n}=3)$ & $11.99-121.9$ \\
\hline
\end{tabular}

${ }^{1}$ DSI-UP $=$ direct steam injected ultrapasteurized; WPC $=$ whey protein concentrate; WPI $=$ whey protein isolate; $\mathrm{WMP}=$ whole milk powder; $\mathrm{SMP}=$ skim milk powders; $\mathrm{MPC}=$ milk protein concentrate; $\mathrm{MPI}=$ milk protein isolate.

${ }^{2}$ Ranges represent the mean range from triplicate extractions from the number of samples listed in parentheses. 
(2018) presented a mechanism for FA formation from glucose degradation, but it was established in a coffee model system. Future studies are required to elucidate FA formation in different types of dairy foods.

Comparing fluid milk content of FA, milks that were subjected to higher heat treatment formed more FA than milks with lower heat treatment. This was also reported by Albouchi and Murkovic (2018) in coffee model systems. Previous studies extracted FA from milks that had been heated at high temperatures (above $140^{\circ} \mathrm{C} / 30$ min or longer) as well (Patton and Josephson, 1949; Patton, 1950; Patton and Flipse, 1957; Berg, 1993). This result demonstrates that higher heat treatment favors formation of FA. This trend was also observed in higher heat SMP compared with lower heat SMP. During 4 wk of storage at $4^{\circ} \mathrm{C}$, significant decreases in FA levels in fluid milk were observed. Previous studies documented changes (increases and decreases) in concentration of FA during wine aging attributed to microbial activity and the relative proportion between furfural and FA (Spillman et al., 1998; Pérez-Prieto et al., 2003). In milk, it would be expected that FA undergoes chemical degradation or conversion during storage, possibly associated with furfural.

Furfuryl alcohol was significantly higher in milk protein powders than in whey protein powders. One hypothesis is that the difference in processing of the 2 powders affected final FA content. Whey protein powders are generally made by concentrating whey from cheese production. The cheese-making process uses lactic starter cultures that convert lactose into lactic acid to drive down $\mathrm{pH}$. With lower levels of starting lactose in the whey, FA content is lower in whey protein powders compared with milk protein powders. Milk protein powders and SMP had increased levels of FA with longer storage time. Maillard reaction products continue to form in milk powders during storage due to the close proximity of reactive molecules (Kelly and Fox, 2016). Furfuryl alcohol, being a product of Maillard reaction, is likely continuing to form in these milk powders as they are stored.

Cheddar cheese had more interesting results, with mild Cheddars having higher concentrations than more sharp Cheddars. Spillman et al. (1998) reported mi-

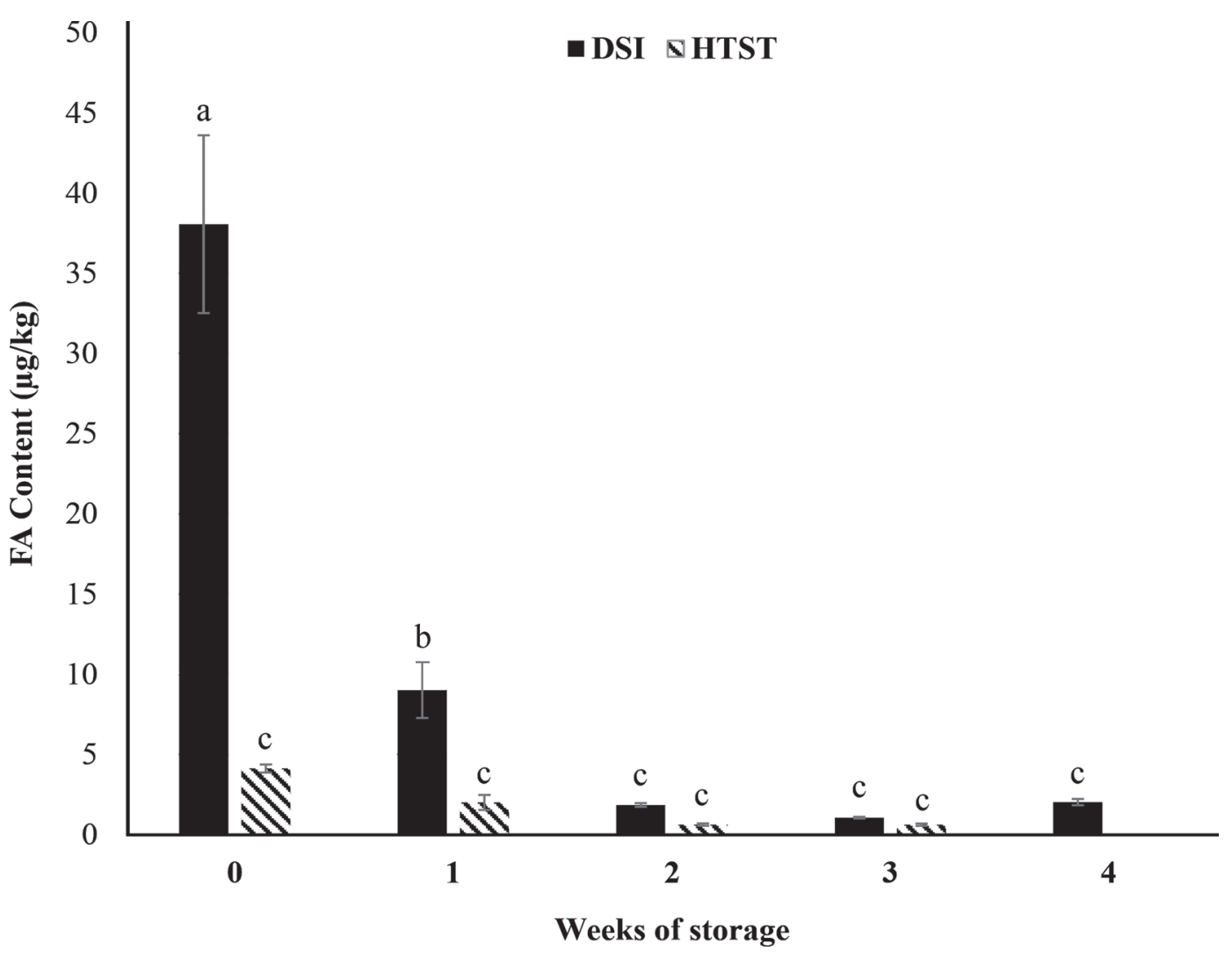

Figure 1. Furfuryl alcohol (FA) concentrations in pilot plant processed fluid skim milk across 4 wk at $3^{\circ} \mathrm{C}$. Means not sharing common letters $(\mathrm{a}-\mathrm{c})$ are different $(P<0.05)$. DSI $=$ direct steam injected ultrapasteurized milk. Error bars indicate SE. Each bar represents the mean of triplicate analyses from 3 different lots of processed milk at each time point. The HTST milk was not evaluated at 4 wk because that was past shelf life. 
croflora converting FA into FA ethers in wine. It is possible that cheese cultures have a similar effect on FA in cheese during the aging process. Longer aged cheeses would experience this effect over a longer period of time and have lower levels of FA. Cottage cheese and sour cream had the lowest levels of FA. This result coincides with previous studies finding no $\mathrm{FA}$ in lower $\mathrm{pH}$ lactose solutions after heating (Patton, 1950). Yogurt also had low levels of FA, with the exception of one Greek-style yogurt, further suggesting low $\mathrm{pH}$ does not favor FA formation in dairy products. Furfuryl alcohol in lower $\mathrm{pH}$ may be subjected to go through chemical degradation. A previous study reported degradation of FA in coffee and noted that FA is able to polymerize in acidic conditions (Swasti and Murkovic, 2012). The study showed that degradation of FA in an acidic medium resulted in the formation of oligomers via the condensation of the hydroxyl group. Future studies should address the effect of $\mathrm{pH}$ on degradation of FA in dairy products. The Greek-style yogurt sample with higher FA content was made by fortifying with milk protein powder, and according to the findings of this paper, milk protein powders can contain up to $121 \mu \mathrm{g} /$ $\mathrm{kg}$ of FA, which would contribute to the high level of FA in the Greek-style yogurt.

\section{CONCLUSIONS}

The analytical approach using HS-SPME-GC-MS/ MS provided a fast and sensitive response for determination of FA content in various dairy products. Using this extraction and detection method, we showed that FA was present in higher levels in dairy products that were subjected to higher heat treatments or were stored for longer periods of time. Dairy products with lower $\mathrm{pH}$, such as sour cream or cottage cheese, had lower levels of $\mathrm{FA}$, suggesting that $\mathrm{pH}$ could play a role in formation or degradation of FA. The current data obtained from over 100 dairy products demonstrates lower FA levels in dairy foods compared with other foods with previously documented concentrations of FA. Despite the differences in detection techniques compared with previous studies, these results suggest a general trend of lower FA concentrations (up to 1,000 -fold lower) in dairy foods than other heated or processed foods.

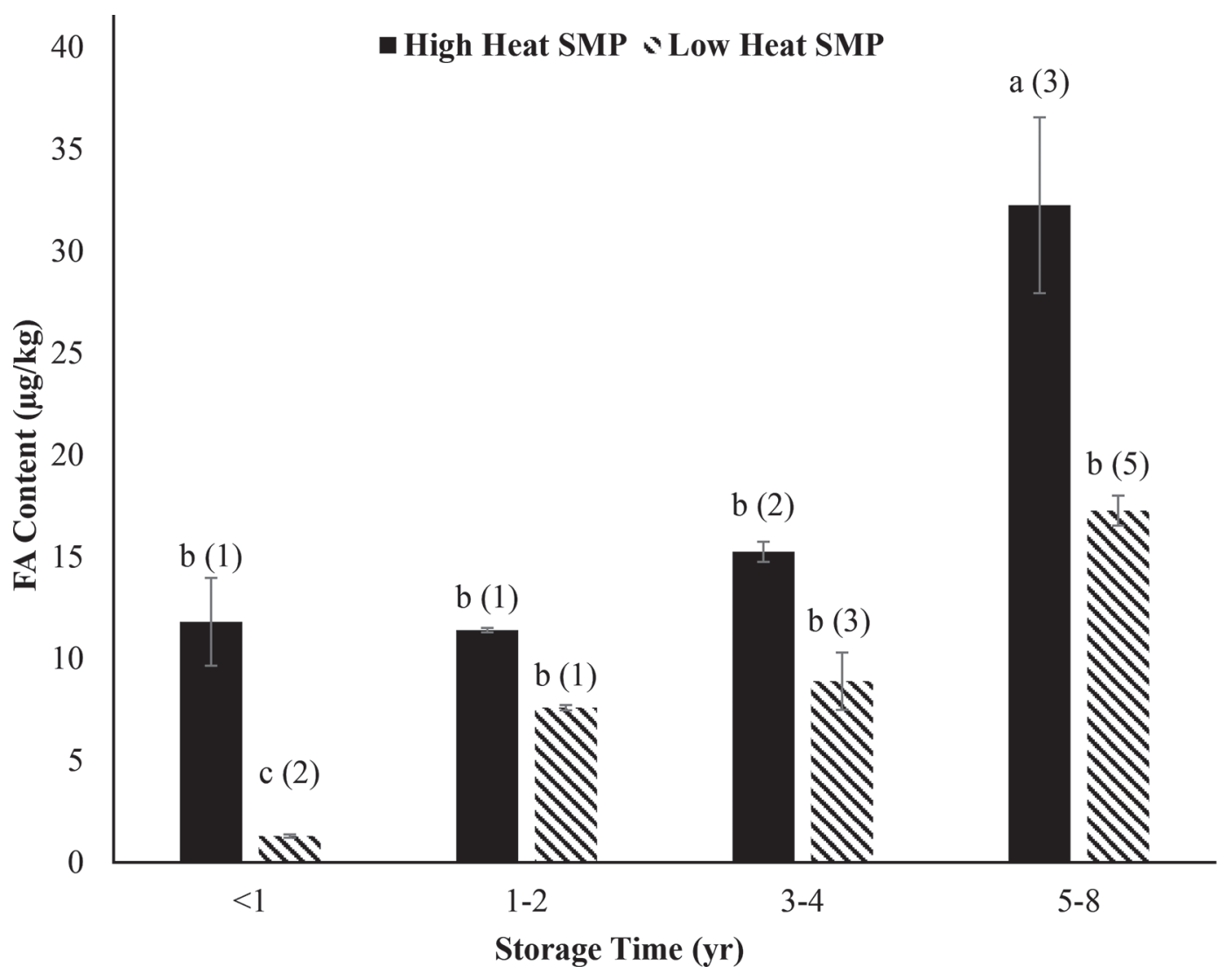

Figure 2. Furfuryl alcohol (FA) content in skim milk powders (SMP) of various ages. Means not sharing common letters (a-c) are different $(P<0.05)$. Error bars indicate SE. Numbers in parentheses above bars represent the number of samples tested. 


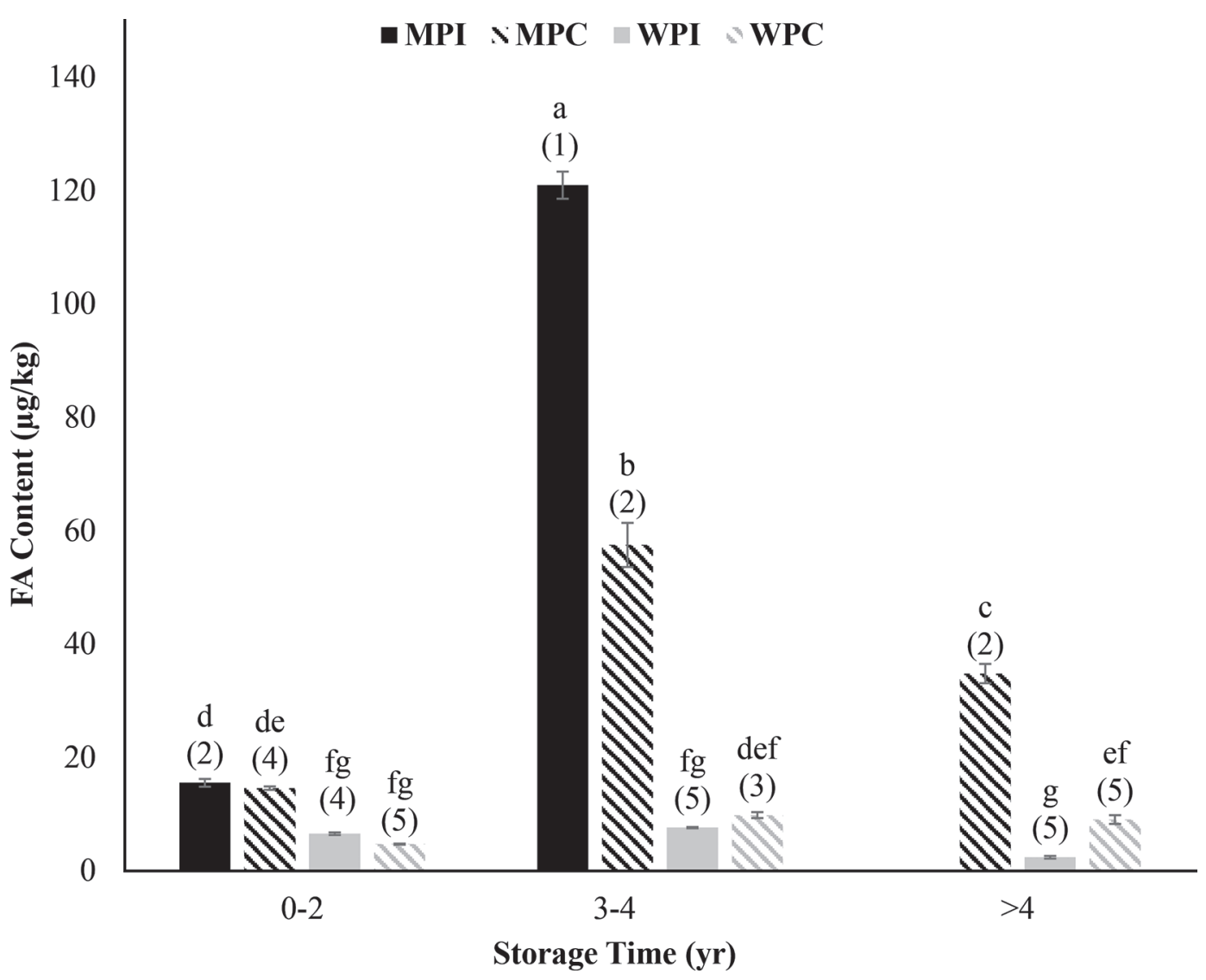

Figure 3. Furfuryl alcohol (FA) content in milk and whey protein powders at storage times ranging from 0 to 6 yr. MPI $=$ milk protein isolate $\mathrm{MPC}=$ milk protein concentrate; $\mathrm{WPI}=$ whey protein isolate; $\mathrm{WPC}=$ whey protein concentrate. Means not sharing common letters $(\mathrm{a}-\mathrm{g})$ are different $(P<0.05)$. Error bars indicate SE. Numbers in parentheses above bars represent the number of samples tested.

\section{ACKNOWLEDGMENTS}

Funding was provided in part by the National Dairy Council (Rosemont, IL). The use of tradenames does not imply endorsement nor lack of endorsement by those not mentioned.

\section{REFERENCES}

Albouchi, A., and M. Murkovic. 2018. Formation kinetics of furfuryl alcohol in a coffee model system. Food Chem. 243:91-95.

American Cancer Society. 2015. Cancer warning labels based on California's Proposition 65. Accessed Jul. 23, 2018. https://www .cancer.org/cancer/cancer-causes/general-info/cancer-warning -labels-based-on-californias-proposition-65.html.

Berg, H. E. 1993. Reactions of lactose during heat treatment of milk: A quantitative study. $\mathrm{PhD}$ thesis. Wageningen Agricultural University, Integrated Food Science and Food Physics Department, Wageningen, the Netherlands.

Bonvehi, J. S. 2005. Investigation of aromatic compounds in roasted cocoa powder. Eur. Food Res. Technol. 221:19-29.

California Environmental Protection Agency. 2018a. About Proposition 65. Accessed Jul. 23, 2018. https://oehha.ca.gov/proposition -65 /about-proposition- 65 .

California Environmental Protection Agency. 2018b. Foods. Accessed Jul. 30, 2018. https://www.p65warnings.ca.gov/fact-sheets/foods.
California Environmental Protection Agency. 2018c. Furfuryl alcohol. Accessed Jul. 23, 2018. https://oehha.ca.gov/proposition-65/ chemicals/furfuryl-alcohol.

Carunchia Whetstine, M. E. C., K. R. Cadwallader, and M. A. Drake. 2005. Characterization of aroma compounds responsible for the rosy/floral flavor in cheddar cheese. J. Agric. Food Chem. 53:31263132.

Condurso, C., F. Cincotta, and A. Verzera. 2018. Determination of furan and furan derivatives in baby food. Food Chem. 250:155-161.

Evans, J., J. Zulewska, M. Newbold, M. A. Drake, and D. M. Barbano. 2009. Comparison of composition, sensory, and volatile components of thirty-four percent whey protein and milk serum protein concentrates. J. Dairy Sci. 92:4773-4791.

Glatt, H., and Y. Sommer. 2006. Health risks of 5-hydroxymethylfurfural (HMF) and related compounds. Pages 328-357 in Acrylamide and Other Hazardous Compounds in Heat-Treated Foods, Vol. 1. K. Skog and J. Alexander, ed. Woodhead Publishing, Cambridge, UK.

Høie, A. H., B. H. Monien, A. K. Sakhi, H. Glatt, H. Hjertholm, and T. Husey. 2015. Formation of DNA adducts in wild-type and transgenic mice expressing human sulfotransferases $1 \mathrm{~A} 1$ and $1 \mathrm{~A} 2$ after oral exposure to furfuryl alcohol. Mutagenesis 30:643-649.

Jo, Y., D. M. Benoist, D. M. Barbano, and M. A. Drake. 2018. Flavor and flavor chemistry differences among milks processed by high temperature short time or ultra-pasteurization. J. Dairy Sci. 101:3812-3828.

Karagül-Yüceer, Y., K. R. Cadwallader, and M. A. Drake. 2002. Volatile flavor compounds of stored nonfat dry milk. J. Agric. Food Chem. 50:305-312. 
Kelly, A. L., and P. F. Fox. 2016. Manufacture and properties of dairy powders. Pages 1-33 in Advanced Dairy Chemistry Vol. 1. Part B. P. L. H. McSweeney and O. Mahoney, ed. Springer Science, New York, NY.

Lee, A. P., D. M. Barbano, and M. A. Drake. 2017. The influence of ultrapasteurization by indirect and direct steam injection processing on sensory perception of skim and $2 \%$ fat milks. J. Dairy Sci. 100:1688-1701.

Lee, S. M., B. C. Seo, and Y. S. Kim. 2006. Volatile compounds in fermented and acid-hydrolyzed soy sauces. J. Food Sci. 71:146-156.

Mahajan, S. S., L. Goddik, and M. C. Qian. 2004. Aroma compounds in sweet whey powder. J. Dairy Sci. 87:4057-4063.

Milo, C., and G. A. Reineccius. 1997. Identification and quantification of potent odorants in regular-fat and low-fat mild cheddar cheese. J. Agric. Food Chem. 45:3590-3594.

Monakhova, Y. B., W. Ruge, T. Kuballa, M. Ilse, O. Winkelmann, B. Diehl, F. Thomas, and D. W. Lachenmeier. 2015. Rapid approach to identify the presence of Arabica and Tobusta species in coffee using 1H NMR spectroscopy. Food Chem. 182:178-184.

Monien, B. H., K. Herrmann, S. Florian, and H. Glatt. 2011. Metabolic activation of furfuryl alcohol: Formation of 2-methylfuranyl DNA adducts in Salmonella typhimurium strains expressing human sulfotransferase $1 \mathrm{~A} 1$ and in $\mathrm{FVB} / \mathrm{N}$ mice. Carcinogenesis 32:1533-1539.

Okaru, A. O., and D. W. Lachenmeier. 2017. The food and beverage occurrence of furfuryl alcohol and myrcene-Two emerging potential human carcinogens? Toxics 5:9.

Park, C. W., and M. A. Drake. 2016. Condensed milk storage and evaporation affect the flavor of nonfat dry milk. J. Dairy Sci. 99:9586-9597.

Patton, S. 1950. Studies of heated milk III: Mode of formation of certain furan compounds. J. Dairy Sci. 33:904-910.

Patton, S., and R. J. Flipse. 1957. Carbon-14 activity of some heatdegradation products of milk containing lactose-1- $\mathrm{C}^{14}$. Science 125:1087-1088.
Patton, S., and D. V. Josephson. 1949. The isolation of furfuryl alcohol from heated skim milk. J. Dairy Sci. 32:222-227.

Pérez-Prieto, L. J., J. M. López-Roca, A. Martínez-Cutillas, F. PardoMínguez, and E. Gómez-Plaza. 2003. Extraction and formation dynamic of oak-related volatile compounds from different volume barrels to wine and their behavior during bottle storage. J. Agric. Food Chem. 51:5444-5449.

Qian, M., and G. Reineccius. 2002. Identification of aroma compounds in Parmigiana-Reggiano cheese by gas chromatography/olfactometry. J. Dairy Sci. 85:1362-1369.

Ramshaw, E. H., and E. A. Dunstone. 1969. Volatile compounds associated with the off-flavor in stored casein. J. Dairy Res. 36:215223.

Spillman, P. J., A. P. Pollnitz, D. Liacopoulos, K. H. Pardon, and M. A. Sefton. 1998. Formation and degradation of furfuryl alcohol, 5-methylfurfuryl alcohol, vanillyl alcohol, and their ethyl ethers in barrel-aged wines. J. Agric. Food Chem. 46:657-663.

Swasti, Y. R., and M. Murkovic. 2012. Characterization of the polymerization of furfuryl alcohol during roasting of coffee. Food Funct. 3:965-969.

Vázquez, L., A. Verdú, A. Miquel, F. Burló, and A. A. CarbonellBarrachina. 2007. Changes in physico-chemical properties, hydroxymethylfurfuryl and volatile compounds during concentration of honey and sugars in Alicante and Jijona turron. Eur. Food Res. Technol. 225:757-767.

Wang, Y., and S. J. Kays. 2000. Contribution of volatile compounds to the characteristic aroma of baked Jewel sweetpotatoes. J. Am. Soc. Hortic. Sci. 125:638-643.

White, S. S., K. M. Fox, S. M. Jervis, and M. A. Drake. 2013. Influence of heating and acidification on the flavor of whey protein isolate. J. Dairy Sci. 96:1366-1379.

Yaylayan, V. A., and A. Keyhani. 2000. Origin of carbohydrate degradation products in L-alanine/D-[13C] glucose model systems. J. Agric. Food Chem. 48:2415-2419. 